\title{
POLITIK IDENTITAS ETNIK ASLI PAPUA BERKONTESTASI DALAM PEMILIHAN KEPALA DAERAH DI KOTA SORONG
}

\author{
Ferinandus Leonardo Snanfi, Muhadjir Darwin, Setiadi, dan Hakimul Ikhwan \\ Program Studi S3 Studi Kebijakan Universitas Gadjah Mada \\ E-mail: ferisnanfi@yahoo.com
}

\begin{abstract}
ABSTRAK. Tujuan penelitian, (1) Untuk mengetahui bagaimana politik identitas etnik asli Papua berkontestasi merebut kekuasaan dalam pemilihan kepala daerah di Kota Sorong. (2) Untuk mengetahui bagaimana etnik asli Papua berkolaborasi dengan etnik non Papua dalam merebut kekuasaan dalam pemilihan kepala daerah di Kota Sorong. Metode penelitian kualitatif. Hasil penelitian menunjukkan (1) Otonomi khusus melahirkan politik identitas etnik, egoisme kampung, marga, budaya, saudara, untuk merebut kekuasaan dalam pemilihan kepala daerah di Kota Sorong. Kedua etnik asli Papua saling marginalisasi dalam strategi isu kampaye politik identitas, family, marga, kampung, organisasi etnik, gereja, televisi,spanduk, koran, elit DPRD Kota. Kedua etnik tidak bersatu dikarenakan egosime budaya, adat, diantara kedua etnik asli Papua itu sendiri di Kota Sorong. Tujuan politik identitas etnik untuk menguasai sumber daya ekonomi (dana) otsus Kota Sorong. (2) Alasan etnik asli Papua berkolaborasi dengan etnik non Papua dikarena etnik Maybrat mempunyai perjanjian politik yaitu etnik Maybrat walikota dan etnik Makassar wakil walikota dalam pemilihan kepala daerah di Kota Sorong. Serta mengguasai pasar umum, transportasi kendaraan umum.
\end{abstract}

Kata kunci: Politik Identitas Etnik, Asli Papua Berkontestasi, Pemilihan Kepala Daerah.

\section{THE IDENTITY POLITICS OF PAPUAN INDIGENOUS ETHNICS IN CONTESTATION OF REGIONAL CHIEF ELECTION IN SORONG CITY}

\begin{abstract}
This research was aimed (1) to know the identity politics of Papuan indigenous ethnics identity in contesting to seize power in regional chief election of Sorong City. (2) to know how Papuan indigenous ethnics in collaboration with non-Papuan ethnics in seizing power of regional chief of Sorong City. Qualitative research method was used.The research results showed that (1) Special Autonomy (Otsus) bring forth identity politics of village egoism ethnics, margaism, culture, family, to seize power in voting regional chief in Sorong City. Both Papuan indigenous ethnics marginalized to each other in issues of primordialism identity politic campaign, village, culture, clan, language. Strategy of issues of identity politics campaign, family, clan, village, ethnical organization, church, television, banner, newspaper, elite of city DPRD. Both ethnics did not unity because of cultural egoism, custom, among both Papuan indigenous ethnics themselves in Sorong city. The political objective of ethnics identity is to dominate economic resource of Otsus's fund of Sorong City. (2) the reason of Papuan ethnics collaborated with non-Papuan ethnics are for the political agreement in seizing power in voting regional chief in Sorong City, Maybrat ethnics for major and Makassar ethnics for deputy major. The collaboration has dominated the public market, public transportation and easy to get custom land.
\end{abstract}

Key words: Ethnics Identity Politics, Papuan Indigenous to Contest, Regional Chief Election.

\section{PENDAHULUAN}

Tujuan penelitian ini, melihat politik identitas etnik asli Papua yaitu, etnik Maybrat dan etnik Moi menggunakan identitasnya masing-masing dalam berkontestasi merebut kekuasaan dalam pemilihan kepala di Kota Sorong. Politik identitas etnik itu, dimainkan dalam kehidupan sehari-hari. Etnik Maybrat dan etnik Moi. Dari budaya, adat, kampung, keluarga, marga dan egoisme etnik masing-masing yang tertanam dalam diri mereka berdua dan ingin mendominasi diantara satu etnik dengan yang lainnya. Berbagai akatifitas seharihari dari, pendidikan, politik, birokrasi pemerintahan dan sebagainya dalam kehidupan sehari-hari di Kota Sorong.

Etnik Maybrat dan etnik Moi, sehari-hari menggunakan identitasnya dalam ranah dinamika politik pemilihan kepala daerah yang di selengarai oleh Komisi Pemilihan Umum Daerah Republik Indonesia, dalam pesta lima tahunan sekali dalam kontestasi politik lokal di Kota Sorong. Kedua etnik Maybrat dan etnik Moi memajukan pemimpin yang berkualitas dari keduan etnik dalam mencalonkan dirinya. Namun mereka dua tidak, bergandengan tanggan bersama untuk merebut kekuasaan di Kota Sorong. Kenapa kedua etnik asli Papua ini tidak bergandengan tanggan untuk merebut kekuasan di Kota Sorong, itu disebabkan karena ada egoisme kulurtur dari budaya, etnik, marga, kampung dan sebangainya.

Dinamika dalam proses masa-masa kampaye inilah, dikeluarkan politik identitas keduanya etnik Maybarat dan etnik Moi. Identitas yang di politisir sebagai "alat" mempersatukan kelompok-kelompok etnik dari, keluarga, kampung, marga, ipar, om, dan sebagainya, masing-masing antara etnik Maybrat dan etnik Moi dalam merebut kekuasaan di Kota Sorong. Proses kampaye politik identitas etnik Maybarat dan etnik Moi, saling memarginalisasi satu dengan yang lainnya dalam isu-isu politik identitas etnik kepada etniketnik asli Papua dan etnik non Papua di Kota Sorong. Isu-isu kampaye politik identitas etnik yang dikemas rapi oleh etnik Moi dan dikeluarkan dari, etnik, keluarga, kampung, marga, egoisme. isu kampaye, pemerintahan satu kampung etnik mengguasai birokrasi, satu etnik 
mengguasai bantuan pemerintah, pejabat yang mengisi jabatan di birokrasi tidak kemampuan karena hasil etnik pemimpin di birokrasi menujut dari etniknya, dan satu etnik yang mengguasai dana Otsus, DAK, DAU, APBD, PAD dan proyek-proyek di Kota Sorong.

Isu-isu kampaye politik identitas etnik yang dikeluarkan oleh etnik Maybarat kepada etnik-etnik asli Papua (etnik yang bayak dari segi jumlah etnik Teminabuan dan etnik Raja Ampat di kota sorong) dan non Papua di Kota Sorong yaitu, jangan salah memilih, kalau tidak mau tanah, rumah, usahmu di ambil kembali oleh etnik Moi kalau etnik Moi yang kekuasaan, etnik Moi tidak mempunyai tidak mempunyai kemampuan dalam memimpin dan merangkung etnik asli Papua dan etni non Papua, etnik Moi buka tokoh pembangunan di Kota ini. Dari permainan politik identitas etnik ini, sudah ada dua irisan saling memarginalisasi yang tajam dimainkan dalam politik lokal. Maka ini bisa dikatakan kalau satu etnik yang berkuasa diantara mereka dua akan marginalisasi etnik yang satu dalam bentuk politik, didalam birokrasi pemerintahan atau dalam aktifitas pemerintah di Kota Sorong.

Etnik non Papua Bugis, Buton, Makassar, Ambon, dan Toraja, (selanjutnya disingkat BBMAT, diambil etnik ini di Kota Sorong banyak segi jumlah etniknya). Etnik non Papua (BBMAT) disini tidak menojolkan politik identitasnya. Karena etnik non Papua pihak yang berkolaborasi dengan kedua etnik asli Papua yang berkontestasi dan saling memarginalisasi satu dalam bentuk kampaye yang didulis diatas. Etnik non Papua disini melihat kelebihan dan kekurangan politik yang dimainkan kedua etnik asli Papua dalam merebut kekuasaan di Kota Sorong. Dan etnik non Papua memberikan dukungan lewat berbagai cara seperti, organisasi-organisasi etnik, DPRD Kota, dan pejabat etnik di birokrasi yang mempunyai pengaruh di lingkungan tempat tinggal. Perjanjian-perjanjian politik yang disepakati oleh kedua etnik Maybrat dan etnik non Papua dalam merebut kekuasaan itu, dalam berbagai kekuasan didalam birokrasi pemerintahan dan diluar birokrasi pemerintahan. Maka semua dukungan suara mayoritas etnik non Papua diberikan kepada etnik Maybrat dan etnik Makassar untuk merebut kekuasaan dalam pemilihan kepala daerah di Kota Sorong.

Otonomi khusus di Provinsi Papua dan Provinsi Papua Barat, agar semua etnik asli Papua bergandengan tangan membangun daerahnya sesuai dengan kondisi di wilayah Papua. Dengan demikian, akan terjadi pembangunan ekonomi masyarakat, percepatan pembangunan sumber daya manusia, percepatan pembangunan institusi pemerintah, dan percepatan pendidikan politik bagi masyarakat dan sebagainya. Sayangnya hal tersebut terkendala dengan fakta yang ditulis diatas sebelumnya. Ini bisa menegaskas kepada semua etnik-etnik asli Papua, etnik non Papua yang ada di Kota Sorong dan etnik yang diluar Papua bawah etnik-etnik Papua di Kota Sorong, itu tidak bersatu dalam pelaksanan Otsus, setiap etnik-etnik lebih bersatu kepada hubungan kelompok-kelompok etnik dari identitasnya dari, kampung, marga, keluarga ipar, om, saudara dalam hubungan darah dan kelompok politik. Dibandingkan persatuan kepapuaan, dan etnik-etnik Papua di Kota Sorong, saling marginalisasi satu dengan yang lainnya dan ingin tampil menojol, "mengecilkan" identitas etnik-etnik Papua yang lain. Maka memainkan politik identitas etnik dalam kelompok-kelompoknya untuk merebut kekuasaan di Kota Sorong.

Maka Dari masalah yang diuraikan diatas peneliti tertarik menganalisis dampak proses kerja politik identitas etnik yang dimainkan kedua etnik asli Papua yaitu etnik Maybrat dan etnik Moi dan juga melibatkan etnik non Papua untuk berkolaborasi dalam menjalankan politik identitas etnik untuk merebut kekuasaan dalam pemilihan kepala daerah di Kota Sorong.

Berdasarkan dari uraian latar belakang masalah yang telah dipaparkan di atas, maka perumusan masalah pokok dalam penelitian ini, sebagai berikut:

1. Bagaimana politik identitas etnik asli Papua berkontestasi merebut kekuasaan dalam pemilihan kepala daerah di Kota Sorong ?

2. Bagaimana etnik asli Papua berkolaborasi dengan etnik non Papua dalam merebut kekuasaan dalam pemilihan kepala daerah di Kota Sorong?

Maka tujuan dari Penelitian ini ialah:

1. Untuk mengetahui Bagaimana politik identitas etnik asli Papua berkontestasi merebut kekuasaan dalam pemilihan kepala daerah di Kota Sorong.

2. Untuk mengetahui Bagaimana etnik asli Papua berkolaborasi dengan etnik non Papua dalam merebut kekuasaan dalam pemilihan kepala daerah di Kota Sorong.

\section{METODE}

Metode penelitian kualitatif, Nasir (1988: 64). Nawawi (2001:167), informan yang diambil 52 informan dari representasi PNS tingkat OPD etnik Maybrat dan etnik Pendatang, PNS dari etnis-etnis yang termarginalisasi, Tokoh-tokoh masyarakat dari etnis-etnis asli Papua serta etnis Pendatang, Tokoh Agama, masyarakat Moi, masyarakat Pendatang, masyarakat Teminabuan, masyarakat Raja Ampat, masyarakat Maybrat, didalam birokrasi pemerintahan dan di masyarakat Kota Sorong. Teknik pengumpulan data primen yaitu, wawancara yang sifatnya spontan,objektif, tidak rekayasa. (Salim, 2006:223). wawancara mendalam suasana keakraban dengan mengajukan pertanyaan (Bungin, 2005: 108). Observasi sistematis pada obyek penelitian (Nawawi, 1991:100), observasi sederhana non partisipasi, mencatat pengamatan. Observasi melalui pengamatan dan pengindraan (Bugin, 2005: 115). teknik pengumpulan data sekunder, menurut Bungin (2001:152), dokumen foto- 
foto, karya ilmiah. analisis data penelitian menggunakan M.B. Miles dan A.M. Huberman Singarimbun dan Effendi (1995: 163).

\section{HASIL DAN PEMBAHASAN}

\section{Proses Kerjanya Politik Identitas Etnik Maybrat Dalam Pemilihan Kepala Daerah di Kota Sorong}

Proses Politik identitas etnik yang dimainkan kedua etnik asli Papua yaitu etnik Maybrat dengan etnik Moi dalam pemilihan kepala daerah di Kota Sorong. Isu-isu identitas yang dipertontongkan sangat menojol dengan politik identitas, saling serang dalam isu-isu yang menjadi buah bibir dikalangan etnik Papua dan etnik non Papua di Kota Sorong. Kubangun (2014:3) yang menyebutkan bahwa, kontestasi di antara orang asli Papua berdasarkan ikatan primordialisme semakin menguat. Dalam isu kampaye yang digunakan politik identitas oleh etnik Maybrat kepada etnik Moi yaitu: etnik Papua dan etnik non Papua kami (etnik Maybrat) adalah tokoh pemekaran, etnik Maybrat yang membuat kota ini maju di tanah Papua, etnik Maybrat yang bisa menyatukkan etnik asli Papua dan etnik non Papua di Kota, etnik Maybrat yang membuat kota ini aman serta bisa berdangan dari pagi sampai pagi, jika etnik Papua, etnik non Papua, salah memilih maka etnik Papua dan etnik non Papua, akan kehilangan tanah, rumah, usah karena mereka (etnik Moi), berkuasa maka tanah adat mereka di ambil kembali. Mengunakan simbol-simbol baju, mahkota, bahasa daerah setiap berkampaye di etnik Papua dan etnik non Papua, mengatakan bawah etnik Maybrat yang bisa merangkung semua etnik-etnik dan agama-agama di Kota Sorong (Sumber: wawancara dengan Bapak YN Kepala etnik Maybrat Sabtu, 16 September 2017. Jam 11;00 WIT).

Isu kampaye politik identitas, yang dimainkan kepada internal etnik Maybrat itu sendiri. Ini bukan pertarungan merebut jabatan untuk individu atau kelompok yang memberikan dukungan. Tetapi masalah harga diri etnik Maybrat dari keluarga, marga, kampung yang dipertarukan dalam merebut kekuasan di Kota Sorong. Semua pejabat-pejabat yang memberikan dukungan politik kepada etnik Maybrat di setiap basis atau lingkungan kelurahan dalam merebut kekuasaan di Kota Sorong. Diangkat atau dipertahankan dalam pengisian jabatan struktural. Kampaye politik identitas etnik meberikan bantuan pelayanan pemerintah kepada etnik Papua dari air bersih, jalan raya, penerangan jalan, dan membuka lapangan perkerjaan kepada etnik Papua ( Sumber: wawancara dengan Bapak YN Kepala etnik Maybrat Sabtu, 16 September 2017. Jam 11;00 WIT).

\section{Proses Kerjanya Politik Identitas Etnik Moi Di Dalam Pemilihan Kepala Daerah Kota Sorong} Isu kampaye politik identitas etnik yang dikemas dalam politik identitas etnik Moi. Etnik asli Papua dan etnik non Papua, oleh etnik Moi kepada etnik Maybrat di Kota Sorong yaitu. Isu Identita etnik dalam internal etnik Moi kita harus menjadi tuan di atas tanah leluhur tanah malamoi, supaya kita bisa membangun dan menjaga alam kita (etnik Moi) sendiri yang ditinggalkan oleh leluhur etnik Moi, etnik Maybrat sudah menjadi berkuasa di kota sorong, tetapi mereka selalu diskriminasi membawah etniknya dalam menguasai birokrasi dari atasan sampai bawahan di birokrasi pemerintahan Kota Sorong, mereka selalu diskriminasi dalam memberikan bantuan pemerintah kepada etnik-etnik yang lainnya (Sumber: wawancara dengan Bapak SK Ketua lembanga masyarakat Adat malamoi jumat, 1 September 2017. jam 9; 00 WIT).

Isu kampaye politik identitas etnik yang disebarkan oleh etnik Moi kepada etnik Maybrat menggunakan politik yang kurang bagus dalam daftar pemilihan tetap ada penambahan nama-nama orang-orang yang kurang jelas tempat tinggalnya dan menggunakan politik uang kepada masyarakat yang memilihnya, isu politik identitas yang dimainkan satu kampung etnik Maybrat menguasai jabatan publik semua di Kota Sorong, dari ketua umum DPRD Kota, Anggota DPRD Kota semuanya dikuasai oleh etnik Maybrat saja dan tidak ada etnik lain di Kota sorong, etnik Maybrat terlalu egoisme dan KKN.

\section{Strategi Aktor-Aktor Elite dari Etnik Maybrat dan Etnik Moi dalam Kontestasi Politik Identitas Etnik dalam Pemilihan Kepala Daerah di Kota Sorong}

Kontestasi politik identitas yang dimainkan oleh aktor-aktor kedua etnik asli Papua, yaitu etnik Maybrat dan etnik Moi, dalam merebut kekuasaan politik pemilihan kepala daerah di Kota Sorong. Proses Politik identitas etnik yang dimainkan kedua etnik asli Papua yaitu etnik Maybrat dengan etnik Moi dalam pemilihan daerah untuk merebut kursi nomor satu di Kota Sorong. Dengan mengunakan Isu-isu identitas yang dipertontongkan sangat menojol dengan politik identitas, saling serang dalam isu-isu yang menjadi buah bibir dikalangan etnik Papua dan etnik non Papua di Kota Sorong. Isu kampaye yang digunakan politik identitas oleh etnik Maybrat kepada etnik Moi yaitu: etnik Papua dan etnik non Papua kami (etnik Maybrat) adalah tokoh pemekaran, etnik Maybrat yang membuat kota ini maju di tanah Papua, etnik Maybrat yang bisa menyatukkan etnik asli Papua dan etnik non Papua di Kota, etnik Maybrat yang membuat kota ini aman serta bisa berdangan dari pagi sampai pagi, jika etnik Papua, etnik non Papua, salah memilih maka etnik Papua dan etnik non Papua, akan kehilangan tanah, rumah, usah karena mereka (etnik Moi), berkuasa maka tanah adat mereka di ambil kembali. Mengunakan simbol-simbol baju, mahkota, bahasa daerah setiap berkampaye di etnik Papua dan etnik non Papua, mengatakan bawah etnik Maybrat yang 
bisa merangkung semua etnik-etnik dan agama-agama di Kota Sorong (Sumber: wawancara dengan Bapak YN Kepala etnik Maybrat Sabtu, 16 September 2017. Jam 11;00 WIT).

Etnik Moi memainkan politik identitas dengan mengembangkan isu di masyarakat bahwa jika warga etnik mereka tidak terpilih, maka tanah-tanah adat Malamoi di Kota Sorong akan mereka sita atau ditarik kembali. Mereka yang tidak memilih warga etnik Moi tidak akan diakui sebagai pemilik hak adat yang sah di atas tanah lelurnya di Kota Sorong. Di samping itu, etnik Moi juga membangun komunikasi dengan etnik pendatang untuk bersama-sama merebut kursi nomor satu di Kota Sorong. Mereka juga membangun politik identitas etnik di masyarakat dengan menggalang dukungan lewat, kampung, marga,om, ipar, saudara, partai politik, hubungan keluarga, dan gereja.

Aktor-aktor elite dari etnik Maybrat dan etnik Moi memainkan strategi yang berbeda dalam kontestasi politik identitas etnik untuk pemilihan kepala daerah di Kota Sorong. Menurut Brown (dalam Subianto, 2009:335), mengatakan bahwa identitas kelompok menunjang konstruksi sosial untuk mempromosikan keterwakilan kepentingan kelompoknya. Perilaku sosial politik terkait dengan identitas kelompoknya yang pada momen tertentu dibangkitkan demi kepentingan kelompoknya. Maka ini kita bisa lihat kedua etnik saling memarginakan dan memainkan politik identitas etnik yang kental dengan isu kampungisme, saudaraisme, iparisme, dan gerejaisme. Strategi aktor-aktor etnik Maybarat sangat diunggulkan dalam kontestasi politik identitas etnik ini, dikarena etnik Maybrat sangat cakap bernegosiasi dengan semua etnik asli Papua dan etnik non Papua (BBMTA) di Kota Sorong. Dapat dikatakan bahwa berkuasanya etnik Maybrat selama lebih dari 30 tahun di Kota Sorong membuat mereka berada di posisi tawar yang baik di hadapan etnik lainnya. Etnik Maybrat juga telah menguasai sumber daya ekonomi yang penting di Kota Sorong, seperti posisi Ketua DPRD Kota Sorong dan Ketua Umum Partai Golkar yang selalu menang selama 30 tahun di Kota Sorong. Warga etnik Maybrat juga menguasai DPRD Kota dari berbagai partai politik yang berbeda dan menguasai sumber daya ekonomi (uang) di birokrasi pemerintahan Kota Sorong. Di samping itu, etnik Maybrat juga mempunyai teman politik yang telah mereka bina selama 30 tahun lewat pendidikan di universitas, perdangan di pasar, proyekproyek pemerintah, yaitu warga etnik Makassar. Hal itu menjadi kekuatan besar dari kontestasi politik dalam strategi yang dibangun oleh aktor-aktor elite Maybrat dan tidak dapat dikalahkan oleh etnik Moi atau etnik lain yang mau bersaing merebut kursi nomor satu di Kota Sorong.

Strategi politik aktor-aktor etnik Moi sangat mudah terbaca dalam kontestasi politik pemilihan kepala daerah karena mereka tidak menguasi sumber daya yang paling penting, yaitu uang. Warga etnik Moi tidak tersebar di posisi-posisi penting di partai politik atau menduduki banyak kursi DPRD Kota Sorong. Mereka pun tidak pernah menguasai jabatan-jabatan penting birokrasi Kota Sorong. Oleh karena itu, politik identitasnya kurang diminati oleh etnik asli Papua dan etnik non Papua. Dikatakan bahwa undang-undang otonomi khusus yang diberikan oleh pemerintah pusat kepada orang Papua pada umumnya dan lebih khusus di Kota Sorong tidak berjalan sesuai harapan, yaitu semua etnik asli Papua harus bergandengan tangan untuk memajukan daerahnya. Tampak dalam kontestasi politik lokal di Kota Sorong, politik identitas etnik bermain sangat menojol di setiap aktivitas politik dan etnik asli Papua harus saling menjatuhkan dengan strategi-strategi yang tidak dapat dilihat secara kasat mata saja. Seperti isu-isu yang dimainkan oleh etnik Maybrat kepada etnik Moi. Kalau etnik Moi menjadi pemimpin di Kota Sorong, tanah-tanah adat malamoi yang sudah kita miliki dan tempat, membangun rumah akan diambil kembali dan juga akan sulit kita mendapat tanah-tanah adat mereka dalam perbagai proses di Kota Sorong seperti berdangan, pembagunan yang dilakukan oleh pemerintah dan kita etnik semua akan membayar tanah-tanah adat etnik Moi di Kota Sorong. Isu yang dimainkan oleh etnik Moi kepada etnik Maybrat yaitu, sudah cukup lama etnik Maybrat memimpin tetapi semua program untuk etnik mereka dalam berbagai aspek, dan semua jabatan di kuasai oleh etnik mereka.

\section{Etnis Makassar Memberikan Dukungan kepada Etnik Maybrat Dalam Pemilihan Kepala Daerah di Kota Sorong}

Politik pemilihan kepala daerah di Kota Sorong terjadi dinamika kontestasi politik lokal di Kota Sorong, dengan ikut sertanya etnik Makassar dalam politik lokal itu. Maka ini akan berdampak kepada tokoh etnik lokal yang bersaing memperebutkan kekuasaan politik dan akses terhadap sumber daya materil Klinken 2001, (dalam Pandji Santosa, 2010:15). Ini terlihat lobi-lobi politik yang dilakukan dari etnik Maybrat dan etnik Moi, dengan sadar membuat kesepakatan proses nilai tawar politik yang serius kepada etnik non Papua didalam organisasi-organisasi etnik non Papua dan para pejabatpejabat etnik non Papua didalam birokrasi pemerintahan yang mempunyai pengaruh disetiap basis lingkungan dikelurahan etnik di Kota Sorong. Negosiasi politik yang di lakukan etnik Maybrat Dan etnik Moi kepada etnik non Papua. Negosiasi politik etnik Maybrat kepada etnik non Papua lebih tertarik berkolaborasi kepada etnik Maybrat (Sumber: Wawancara dengan bapak MM dari etnik Toraja hari Selasa 5 September 2017. Jam 11; 24 WIT).

Perjanjian-perjanjian politik etnik non Papua kepada etnik Maybrat akan memberikan dukungan politik jumlah suara etnik non Papua semua kepada etnik Maybrat. Untuk merebut kuris nomor satu yaitu walikota sorong dan juga wakil walikota dari etnik Makassar akan 
merebut kuris nomor dua atau wakil walikota sorong. Maka semua perjanjian politik yang harus ditepati dalam perebutan kekuasaan di Kota Sorong. (Sumber: wawancara dengan Bapak HS Wakil ketua KKS. Hari Selasa, 29 Agustus 2017 WIT).

Etnik non Papua di Kota Sorong juga berperan penting dalam dinamika politik yang dimainkan oleh etnik asli Papua keduanya. Namun etnik non Papua disini tidak menggunakan politik identitas yang berbauw etnik atau agama, tetapi politik identitas kesamaan tujuan politik dalam merebut kekuasaan di Kota Sorong. Maka etnik Maybrat walikota dan etnik Makassar wakil walikota Sorong. Etnis Makassar sangat mengetahui kekurangan setiap etnik asli Papua yang mencalonkan kandidatnya dalam perebutan kekuataan di Kota Sorong berdasarkan pengalamannya berkolaborasi dengan etnik Maybrat selama 30 tahun. Untuk melancarkan jalanya merebut kekuasaan itu, etnik Maybrat memberikan janji-janji politik kepada etnik Makassar sebagi ganti dukungannya dan janji-janji itu selalu ditepati. Berdasarkan pembagian kekuasaan yang telah disepakati, etnik Makassar akan mendapatkan kekuasaan di sektor-sektor ekonomi, seperti pasar umum dan transportasi, serta posisi wakil wali kota dan jabatan di dalam birokrasi yang berkuasa atas proyekproyek di Kota Sorong.

Etnik Makassar juga melihat politik identitas yang dibangun oleh etnik Maybrat sangat kuat kental mendominasi, baik di dalam maupun di luar birokrasi (Sumber: wawancara Hari Selasa, 29 Agustus 2017. Jam 16;230 WIT, dengan Bapak HS. Wakil Ketua KKSS di Kota Sorong).

Hubungan komunikasi kelompok etnik Maybrat dengan etnik Makassar sudah terjaling sangat baik satu dengan lainnya dalam komunikasi politik yang di bangun keduanya. Kedua etnik saling menerima gagasan politik atau ide-ide politik yang berbedaan di antara satu dengan yang lainnya, menerima perbedaan etnik, bahasa, agama, dan keduanya menjadikan satu tujuan pikiran dalam tindakan yang rasional dalam memberikan dukungan untuk merebut kekuasaan dalam pemilihan kepalah daerah di Kota Sorong. Maka ini senada yang dikutip menurut Abdillah (2002:16), etnisitas adalah kelompok yang sedikitnya telah menjalin hubungan atau, kontak dengan kelompok etnik yang lainnya, setiap etnik menerima gagasan dan ide-ide perbedaan di antara mereka, baik secara kultur maupun politik. Dalam bahasa lain, etnisitas muncul dalam kerangka hubungan relasional saat berinteraksi. Maka dari hubungan komunikasi politik itu etnik Makassar meyakini bahwa orang nomor satu di Kota Sorong pasti berasal dari etnik Maybrat kemudian etnik Makassar akan menjadi orang kedua di Kota Sorong. Dalam pembagian kue kekuasaan yang diperoleh dari dukungan itu adalah dikuasainya sektor ekonomi, seperti pasar umum dan transportasi, serta sektor swasta dan jabatan birokrasi dan partai politik oleh etnik Makassar. Dari lobi politik untuk memberikan dukungan itu, etnik Makassar juga melihat etnik Maybrat telah menguasai sumber daya ekonomi yang sangat banyak di dalam jabatan birokrasi pemerintahan, mulai dari Ketua Umum Partai Golkar yang selalu memenangi pilkada di Kota Sorong dan Ketua DPRD Kota Sorong. Etnik Makassar juga melihat kuatnya

\section{Etnik Makassar Memberikan Dukungan kepada Etnik Maybrat lewat Partai Politik Dalam Pemilihan Kepala Daerah Di Kota Sorong}

Monuver etnik Makassar dan etnik Maybrat dalam pemilihan kepala daerah di Kota Sorong adalah untuk mempertahankan kursi kekuasaan wali kota dan wakil wali kota Sorong. Dengan demikian, kedua etnik itu melakukan lobi-lobi politik di tingkat elite politik di dalam partai politik dan DPRD Kota Sorong. Di sinilah politik identitas dimainkan sebagai alat pengikat negosiasi di dalam partai politik dan anggota DPRD Kota Sorong, Maka ini senada dengan yang dikutip menurut Nashir (2000) sosiologi politik, teori tentang elite dikembangkan dalam kaitan perjuangan politik untuk meraih posisi utama dari persaingan kekuasaan (Karomani, 2019:169). Diketahui bahwa etnik Maybrat menguasai posisi Ketua Umum Partai Golkar dan Ketua Umum DPRD Kota Sorong, sedangkan etnik Makassar menguasai posisi ketua umum di beberapa partai politik (PPP dan PKB) dan anggota DPRD Kota Sorong (Sumber: wawancara dengan Bapak HS Wakil ketua KKS. Hari Selasa, 29 Agustus 2017 WIT ). Jika digambarkan dalam diagram, berikut ini adalah gambaran Persentase etnik dalam DPRD Kota Sorong.

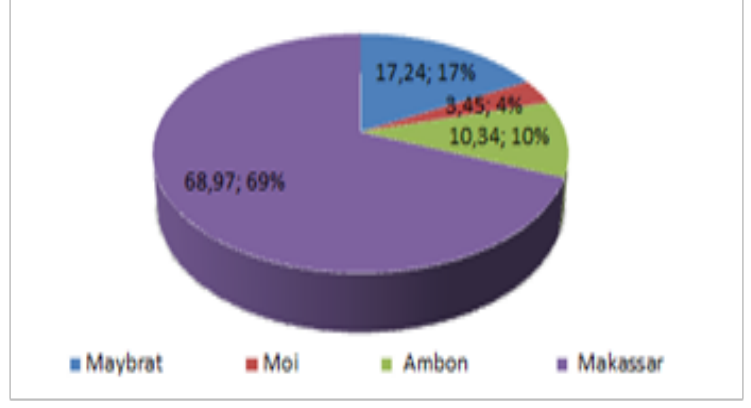

Sumber: Anggota DPRD Kota Sorong, 2017

Gambar 1. Persentase Etnik dalam Jabatan Anggota DPRD Kota Sorong Periode 2014-2019 di Kota Sorong

Berdasarkan gambar itu, diketahui bahwa persentase terbesar yang menduduki posisi anggota DPRD Kota Sorong adalah etnik Makassar dan etnik Maybrat yang diikuti oleh Moi dan etnis Ambon. Kedua etnik yang terakhir juga berkolaborasi memberikan dukungan kepada etnik Maybrat dan etnik Makassar untuk merebut kekuasan dalam pemilihan kepala daerah di Kota Sorong. Negosiasi politik di antara etnik Makassar dan etnik Maybrat sangat solid di tingkat partai politik di Kota Sorong. Dukungan itu juga bertambah besar dengan beberapa aktor elite politik yang berkolaborasi dengan etnik Ambon dan etnik Maybrat. 
Relasi antar etnik terjadi manakala ada interaksi sosial, sebab interaksi sosial adalah awal dari relasi sosial dan komunikasi sosial antara manusia (Liliweri, 2009:125). Ini bisa dilihat etnik Makassar dan Maybrat menjalankan lobi-lobi politik di tingkat partai politik dan anggota DPRD Kota Sorong dengan sangat baik. Dukungan yang diberikan oleh etnik Makassar dalam bentuk menggunakan kekuatan politik identitas etnik keduanya yang secara emosional menggerakkan warga kedua etnik itu. Koalisi kedua etnik itu terbangun dalam partai politik dan DPRD Kota Sorong yang menggerakkan basis-basis kedua etnik di tingkat kelurahan di Kota Sorong. Dengan jalinan politik yang telah berlangsung lama dalam kontestasi politik lokal pemilihan kepala daerah di Kota Sorong, posisi tawar kedua etnik telah terbaca dengan baik. Kedua etnik telah membagi kekuasaan dengan baik di tingkat keanggotaan DPRD Kota Sorong, dan sektor swasta. Hubungan politik yang mesra di antara kedua etnik ini menguatkan dukungan di antara keduanya dan tidak mudah dipatahkan oleh strategi politik yang lainnya.

\section{Etnik Makassar Memberikan Dukungan kepada Etnis Maybrat lewat Organisasi Kerukunannya Dalam Pemilihan Kepala Daerah Di Kota Sorong}

Organisasi ini bertujuan untuk mengoordinasikan semua warga etnik Makassar yang merantau mencari hidup di Kota Sorong. Organisasi ini juga sebagai alat komunikasi dengan masyarakat asli Papua dan etnik non Papua sekaligus menjadi media komunikasi politik bagi etnik-etnik yang memerlukannya. Keberadaan organisasi ini menguatkan posisi aktor elit politik etnik Maybrat untuk meminta dukungan dari etnik Makassar untuk merebut kekuasaan kekuasaan dalam pemilihan kepala daerah di Kota Sorong. Tawaran politik itu tampak dengan posisi wali kota Sorong yang dikuasai etnik Maybrat selama dua periode, sedangkan etnik Makassar mendapat porsi wakil wali kota di Kota Sorong (Sumber: wawancara dengan Bapak HS Wakil ketua KKS. Hari Selasa, 29 Agustus 2017 WIT ).

Perjanjian politik yang dilakukan di antara kedua etnik itu juga menyangkut penguasaan sumber daya ekonomi di birokrasi pemerintahan di Kota Sorong, keanggotaan di DPRD Kota Sorong, serta proyek dan sektor swasta di Kota Sorong. Dukungan dikerahkan etnik Makassar dari basis-basis etnik ini di tingkat kelurahan sampai dengan menggunakan politik identitas untuk mencari dukungan dari mereka yang masih memiliki hubungan darah atau saudara maupun yang kawin dengan etnik Makassar (Sumber: wawancara dengan Bapak YN Kepala etnik Maybrat Sabtu, 16 September 2017. Jam 11;00 WIT).

Thomas Sowell (dalam Liliweri, 2005:9) mengemukakan bahwa kelompok etnik merupakan sekelompok orang yang mempunyai pandangan dan praktik hidup yang sama atas suatu nilai dan norma. Contoh kesamaan nilai di sini adalah kesamaan agama, negara, asal, suku bangsa, kebudayaan, dan bahasa, yang berpayung pada satu kelompok. Maka pendekatan yang dilakukan dalam kesepakatan politik yang dibangun dengan pendekatan melalui organisasi kerukunan etnik Makassar untuk memberikan dukungan kepada etnik Maybrat. Hal itu diterjemahkan dari ketua organisasi dan badan kepengurusannya kepada seluruh warga etnik Makassar yang berada di Kota Sorong. Mereka harus mendukung etnik Maybrat dan etnik Makassar dalam perebutan kekuasaan dalam pemilihan kepala daerah di Kota Sorong.

Melalui organisasi etnik Makassar, mereka yang berasa dirinya adalah bagian dari etnik Makassar harus bersatu dalam semangat keluarga besar etnik Makassar untuk bertarung dalam politik lokal di Kota Sorong. Pertarungan politik itu adalah untuk mendukung berpasangannya etnik Makassar dengan etnik Maybrat dalam merebut posisis orang nomor satu di Kota Sorong. Dengan pengalaman kolaborasi selama 30 tahun, kedua etnik ini telah sangat memahami strategi politik yang harus digunakan untuk memobilisasi dukungan politik dalam merebut kekuasan dalam pemilihan kepala daerah di Kota Sorong.

\section{Budaya Egosentrisme}

Kontestasi dalam politik identitas etnik dalam pemilihan kepala daerah di Kota Sorong, menimbulkan budaya egosentrisme di antara kedua etnik asli Papua, yaitu etnik Maybrat dan etnik Moi. Budaya itu menguat ketika setiap etnik mempertahankan egoisme budaya, kampung, marga, keluarga, bahasa, dan nama baik etnik mereka. Hal itu membuat kedua etnik itu tidak menemukan jalan tengah untuk saling berafiliasi merebut kekuasaan di Kota Sorong. Etnik Maybrat dan etnik Moi berambisi merebut kekuasaan dan menggunakan politik identitas etnik sebagai "kendaraan" politiknya. Keduanya membedakan anggota kelompok etnik yang lain berdasarkan fisik, adat, perkawinan, makanan, minuman, dan hubungan sosial sehari-hari di wilayah mereka di Kota Sorong. Aktor-aktor etnik Maybrat sangat mengetahui kekuatan mereka karena etnik mereka telah berkuasa selama 30 tahun di atas tanah Malamoi Kota Sorong. Etnik itu telah menguasai semua sumber daya ekonomi yang penting mulai dari jabatan-jabatan ketua umum DPRD, birokrasi pemerintahan, partai-partai politik, dan proyek-proyek di pemerintahan. Di samping itu, etnik Maybrat juga menguasai banyak sumber dana yang berasal dari dana APBD, otsus, PAD, DAK, PAD, dan dana lain-lainnya.

Etnik Moi juga mempunyai egoisme yang besar untuk memimpin tanah adat mereka di Kota Sorong. Namun, kelemahan etnik Moi adalah mereka tidak pernah menjadi ketua umum DPRD atau banyak dalam mengisi kursi anggota DPRD dan menguasai jabatanjabatan strategis di birokrasi Kota Sorong. Hal itu 
membuat sumber daya ekonomi (uang) sebagai faktor yang paling penting dalam politik pemilihan kepala daerah di Kota Sorong juga tidak pernah dikuasai etnik Moi. Etnik Maybrat dan etnik Moi saling memarginal dalam pemilihan kepala daerah di Kota Sorong dan saling menggunakan politik identitas etnik masing masing.

Menurut Thomas Sowell (dalam Liliweri, 2005:9) mengemukakan bahwa kelompok etnik merupakan sekelompok orang yang mempunyai pandangan dan praktik hidup yang sama atas suatu nilai dan norma. Contoh kesamaan nilai di sini adalah kesamaan asal, etnik bangsa, kebudayaan, dan bahasa, yang berpayung pada satu kelompok. Maka ini juga sama setiap etnik asli Papua mempunyai satu kelompok kepemimpinan kultural yang mempunyai ikatan-ikatan primordial, seperti derajat, martabat, bahasa, adat istiadat, dan keyakinan yang dibawa sejak lahir. Ikatan-ikatan itu terbawa sampai ke dalam pekerjaan, pendidikan, politik, dan lain-lain. Tidak ada kesepakatan antara etnik Maybrat dan etnik Moi untuk bergandengan tangan merebut kekuasaan di Kota Sorong. Hal itu karena masih kentalnya egoisme budaya, kampung, keluarga, bahasa, derajat, dan martabat dalam diri setiap etnik. Setiap etnik mengatakan bahwa dirinyalah yang paling hebat, sedangkan etnik lainnya berada di bawah etnik mereka. Etnik Maybrat juga mempunyai ambisi yang sangat kuat karena mereka mengetahui bahwa mereka telah menguasai kursi nomor satu di Kota Sorong selama 30 tahun. Penguasaan terhadap kursi nomor satu itu berarti pula bahwa mereka telah banyak menguasai sumber daya ekonomi dari setiap jabatan di birokrasi, partai politik, dan proyek-proyek di pemerintahan. Sementara itu, etnik Moi belum pernah menguasai kursi nomor satu di Kota Sorong dan tidak menguasai sumber-sumber daya ekonomi dari jabatanjabatan penting di birokrasi, partai politik, DPRD Kota Sorong, dan proyek-proyek yang ada di Kota Sorong.

Politik identitas etnik yang dimainkan oleh kedua etnik berakibat pada saling memarginalkan dan berdampak buruk dalam birokrasi pemerintahan Kota Sorong. Dampak negatif di kemudiaan hari adalah fasilitas umum, seperti pasar umum, pelabuan kapal barang, kapal penumpang, dan rumah sakit umum, yang masuk wilayah administrasi Kota Sorong diklaim oleh Kabupaten Sorong ini dikarena dulu administrasi Kota Sorong masih Kabupaten Sorong di simpan administrasi karena ada konflik para elite maka para elite diklaim masuk aset kabupaten Sorong. Berbicara mengenai praktik dominasi aktor, struktur dan pertarungan etnis, sejatinya, dominasi para aktor tersebut cenderung terlibat aktif dalam setiap kontestasi politik baik yang berasal dari partai politik, birokrasi, maupun struktur informal seperti dari organisasi paguyuban, tokoh masyarakat, dan tokoh (aktivis) mahasiswa.

Sementara, jika dilihat dari sejarah perjalanan praktik politik identitas etnis yang berkembang di Sorong saat ini, lebih cenderung melibatkan aktor, serta menyeret penguatan egoisme atas budaya dari masing-masing etnis yang ada di Sorong. Dengan mengedepankan parade kekuatan yang secara alamiah terus terpelihara kepentingannya, maka, Giddens (2009) berpandangan bahwa kepentingan kelompok yang dominan erat berkaitan dengan pelestarianstatus quo. Dengan demikian, bentuk-bentuk makna yang menaturalisasikan kondisi yang telah ada dengan menghambat pengakuan atas sifat masyarakat manusia yang dapat diubah dan berciri historis berperan untuk melanggengkan kepentingan semacam itu. Sepanjang sejarah, kenyataan tersebut dipahami dan dapat mengacu pada kondisi-kondisi ketika relasi sosial tampak memiliki sifat undang-undang alami yang tetap dan tak dapat diganggu gugat, maka, kenyataan identitas tersebut dapat dipandang sebagai bentuk utama keberlangsungan proses naturalisasi masa kini.

Dengan kata lain, sejatinya, penonjolan kekuatan identitas etnik dan relasi yang dilakukan para aktor tersebut pada hakikatnya merupakan pijakan dari kondisi objektif etnisitas yang merasa berpeluang untuk menonjolkan eksistensinya dan tidak melanggar konstitusi, serta cita-cita demokrasi langsung. Dalam hal ini, kondisi dan kedudukan kelompok (identitas) etnis yang ada di Kota Sorong dapat mendorong lahirnya civil society yang kuat di daerah. Dalam konteks Sorong, peran aktor melalui organisasi paguyuban yang berbasis etnis sangat berpengaruh dan dominan dalam kontestasi politik identitas etnik.

Selain itu, keterlibatan aktor birokrat sebagai peran kelompok lapangan tengah yang mempunyai kemampuan untuk mempengaruhi masyarakat pemilih dan jejaringnya jauh lebih efektif dari pada partai politik. Pemetaan lebih lanjut atas dominasi aktor informal dan sturktur formal dalam kontestasi atas etnisk di Kota Sorong, dapat dilihat sampai sejauh mana usaha para aktor dalam membangun isu etnik dalam upaya untuk memetakan masyarakat pemilih berdasarkan garis keturunan dari para kontestan yang tampil sebagai kandidat pemimpin di Kota Sorong. Tidak ada yang bisa menepis, betapa konfigurasi etnik dapat terlihat dengan hadirnya para calon yang akan menduduki kursi kekuasaan di Kota Sorong. Terkait dengan peran kekuatan lapangan tengah yang dalam hal ini para aktor etnik yang mewakili kelompok masing-masing kandidat, mereka terus berupaya untuk melembagakan kekuatan politiknya. Walau secara struktur politik tidak dipandang serupa lembaga partai, namun, kekuatan ini mampu memetakan kekuatan politik para kandidat dengan secara politik yang berbasis etnik.

Tujuan etnik asli Papua berkontestasi merebut jabatan dengan mengunakan berbagai cara dengan membangun isu-isu politik identitas etnik kepada etniketnik Papua dan etnik non Papua di Kota Sorong, lewat saluran kampaye dalam tulisan-tulisan di spanduk, median massa koran dan siayaran televisi lokal di Kota Sorong. Politik yang dimainkan kedua etnik dengan berbagai cara dengan isu politik identitas etnik untuk 
memarginalisasi satu dengan yang lainnya. Maka kedua etnik tersebut menjaling komunikasi kepada etnik Papua dan etnik non Papua untuk bersama-sama berkolaborasi merebut kekuasaan di birokrasi pemerintahan Kota Sorong. Kenapa sampai kedua etnik ini tidak bisa berkolaborasi dikarenakan masih ada faktor egoisme etnik yang dibawah oleh kedua etnik asli Papua. Maka dalam proses-proses kampaye disitu semaking jauh dengan kata bersatu dengan etnik Papua untuk merebut kekuasaan dalam pemilihan kepala daerah di Kota Sorong.

\section{Penyebab Politik Identitas Etnis Dalam Pemilihan Kepala Daerah Di Kota Sorong}

Proses-proses terjadinya politik identitas etnik dalam pemilihan kepala daerah Kota Sorong. Dikarenakan ada hubungan sebelumnya antara etnik Maybrat dengan etnik non Papua di dalam kehidupan sehari-hari. Para elit-elit etnik Maybrat di berikan ilmu pengetahuan (pendidikan) di sebuah lembaga pendidikan (Universitas) yang ternama di Kota Sorong. Didalam menempu pendidikan terjadi kontak-kontak ide-ide politik di antara para elit etnik Maybrat dengan etnik Makassar yang sama. Hubungan yang terbangun diantara kedua etnik itu sangat baik dan saling percaya menggatar kedua etnik tersebut dalam hubungan politik jangka panjang yang serius dalam percaturangan politik lokal dalam pemilihan kepala daerah di Kota Sorong.

Proses-proses politik dalam negosiasi politik antara keduanya etnik Maybrat dengan etnik Makassar berjalan dengan mudah karena sudah disampaikan diatas hubungan sebelumnya antara kedua etnik tersebut. Dari kolaborasi politik dalam merebut kekuasan itu sampai sekarang sudah 30 tahun lamannya mereka dua berkolaborasi. Maka ini sudah ada yang menguasai sektor ekonomi serti etnik Makassar sudah mengasai pasar umum sangat lama, jika kolaborasi itu berubah maka otomasti usaha mereka pasti juga akan berubah karena kolaborasi dengan orang lain.

Kenapa negosiasi etnik Moi tidak diberikan dukungan kepada etnik Makassar. Karena hubungan yang dibangun oleh etnik Makassar dengan etnik Maybrat sudah terbangun sejak lama dan saling percaya diantara kedua belah pihak. Etnik Moi kenapa tidak bisa berkolaborasi kepada etnik Makassar, nantinya mengganggu ekonomi yang sudah berjalan yang dipunyai oleh etnik Makassar dan etnik non Papua yang lain. Tidak ada keperyaan antara etnik Makassar kepada etnik Moi dan etnik Moi tidak menguasai Dana, untuk menjamin dalam proses-proses politik pemilihan kepala daerah dan juga etnik Moi tidak banyak mempunyai dukungan di dalam DPRD Kota Sorong.

Maka untuk mengamankan proses politik di masyarakat pada etnik Papua dan etnik non Papua dimainkan politik identitas etnik dalam pemilihan dan juga untuk mengamankan sumber daya ekonomi di birokrasi pemerintahan, harus mengunakan politik identitas etnik yang menojol dari keluarga, kampung dan marga. Untuk kepentingan menjaga kursi nomor satu dalam pertarungan pemilihan kepala daerah lima tahun lagi. Undang-Undang Otonomi Khusus kepada Provinsi Papua dan Provinsi Papua Barat untuk memperkuatkan etnik-etnik asli Papua dari berbagai aspek, yang berorentasi pada peningkatan sumber daya manusia dan lain-lain sebagainya. Akan tetapi, dalam kenyataannya yang terjadi di daerah timbulnya kontestasi politik identitas etnik di Kota Sorong, dalam politik lokal merebut kekuasaan. Hal itu tergambar dari simbol-simbol primodialisme yang menonjol dalam berbagai aktivitas politik lokal di Kota Sorong.

Maka dari pejelasan diatas dapat mengutip pernyataan Lukmantoro (dalam Bucharim, 2014:20) Politik identitas adalah tindakan politik untuk mengedepankan kepentingan-kepentingan dari anggota-anggota suatu kelompok karena memiliki kesamaan identitas atau karakteristik, baik berbasiskan pada ras, etnisitas. Dari penjelasan politik identitas menurut Lukmantoro (dalam Bucharim, 2014:20), menyebabkan politik identitas etnik menonjol di Kota Sorong untuk penguasan sumber daya ekonomi seperti dana otsus dan lain-lain sebgainya, maka etnik Papua memilih untuk tidak berkolaborasi dengan etnik tertentu di Kota Sorong. dan Memilih etnik lainnya sebagai kawan politiknya. Dan juga alasan di balik pilihan etnik Maybrat yang memilih berkolaborasi dengan etnik Makassar dibandingkan dengan etnik Moi adanya budaya egosentrisme. Sebagaimana diketahui, etnik Maybrat telah menguasai pucuk pemimpin (bupati dan walikota 30 tahun) serta jabatan-jabatan publik di Kota Sorong, partai politik, DPRD Kota Sorong, bahkan Ketua DPRD Kota Sorong, serta juga menguasai proyek-proyek kecil maupun proyek besar yang ada di Kota Sorong. Etnik Maybrat juga menguasai sumber daya ekonomi seperti: Dana Otsus Papua, PAD, DAK, dan DAU di Kota Sorong. Yang juga tidak kalah penting adalah dari segi jumlah penduduk, etnik Maybrat sangat banyak jumlahnya di Kota Sorong dan mempunyai hubungan saudara dengan etnik Teminabuan yang dapat dilihat dari sejarah masa lalu mereka. Hubungan saudara kedua etnik itu, membuat jumlah mereka dua sangat banyak dibandingkan dengan etnik Moi.

Dipilihnya etnik Makassar sebagai etnik yang dirangkul oleh etnik Maybrat untuk berkolaborasi karena etnik Makassar telah menguasai sektor swasta di Kota Sorong. Etnik non Papua, mempunyai banyak sumber ekonomi dalam bentuk pasar umum, ruko, kios, warung makan, transportasi angkutan penumpang maupun angkutan barang, serta kapal-kapal nelayan di Kota Sorong. Etnik Makassar juga menguasai banyak dana yang beredar dari masyarakat kalangan atas maupun kalangan kecil di Kota Sorong. Etnik Makassar juga telah mengetahui kekuatan etnik Maybrat yang telah lama menguasai semua jabatan publik yang telah disebutkan sebelumnya. Dari kolaborasi itu, mereka menekan tanah- 
tanah adat di wilayah Kota Sorong yang merupakan tanah adat etnik Moi agar etnik Maybrat, Teminabuan, Makassar, dan etnik lainnya dapat menguasai tanah mereka dengan mudah yang diatur dalam administrasi birokrasi pemerintahan Kota Sorong.

Namun, politik identitas etnik yang dimainkan itu tidak mengganggu hubungan relasi antara etnik di Kota Sorong, yaitu antara etnik Maybrat dengan etnik Moi, Teminabuan, Raja Ampat, Makassar, Toraja, dan Ambon. Hal yang sama juga berlaku untuk hubungan etnik Moi dengan etnik Maybrat, Teminabuan, Raja Ampat, Makassar, Toraja, dan Ambon, begitu pun sebaliknya, dari etnik Makassar kepada etnik Maybrat, Moi, Teminabuan, Raja Ampat, Toraja, dan Ambon. Hubungan antara etnik terjain dengan baik dan rukun di Kota Sorong, bahkan ini menjadi sebuah catatan penting bahwa dalam permainan politik identitas etnik di Kota Sorong, tidak ada konflik-konflik horizontal yang terjadi. Hal itu membuktikan bahwa etnik-etnik asli Papua dan non Papua di Kota Sorong sangat dewasa dari gaya berpikir dan tindakan setiap individu maupun kelompok-kelompoknya dalam berpolitik di Kota Sorong.

\section{SIMPULAN}

Politik identitas etnik asli Papua berkontestasi merebut kekuasaan di Kota Sorong. Otonomi khusus yang diberikan pemerintahan pusat kepada etnik Papua di Kota Sorong untuk bergadengan tanggan untuk membanguan daerah kota sorong sesuai dengan apa yang mereka alami di Kota Sorong berdampak melahirkan politik identitas etnik dalam proses percaturan politik pemilihan kepala daerah di Kota Sorong, Politik identitas etnik itu dimanfaatkan sebagai alat untuk mempersatukan kelompok-kelompok etniknya untuk kepentingan merebut kekuasaan dalam pemilihan kepala daerah di Kota Sorong. Maka melibatkan identitas etnik dari primodialisme, egoisme kampung, marga, budaya, saudara, dan kelompok politik untuk melebur menjadi satu dalam semangat merebut kekuasaan dalam pemilihan kepala daerah di Kota Sorong. Maka proses kerja politik identitas etnik yang dimainkan oleh etnik Maybrat dan etnik Moi dalam kontestasi politik pemilihan kepala daerah di Kota Sorong, kedua etnik tersebut tidak berkerja sama satu dengan yang lainnya. Kedua etnik maybrat dan etnik etnik Moi saling memarginalisasi satu dengan yang lainnya dengan isu-isu kampaye yang berbauw identitas etnik dari primodialisme, kampung, budaya, marga, bahasa, baju adat, mahkota, dan kelompok politik. Strategi-strategi isu kampaye politik identitas yang dimainkan kedua etnik Maybrat dan etnik Moi melibatkan, family, marga, kampung, organisasi etnik asli Papua dan non Papua,gereja, siaran televisi lokal,spanduk, korang dan para elit politik di DPRD kota dan para pejabat-pejabat birokrasi yang mempunyai basis-basis etnik di keluarahan. Kedua etnik Maybrat dan etnik Moi tidak bersatu dan berkerja sama dalam merebut kekuasaan dalam politik lokal di kota sorong ini dikarenakan masih kuatnya egosime budaya, adat, etnik lebih kuat dan menojol diantara kedua etnik asli Papua itu sendiri. Dan juga tujuan mendasar dari politik identitas etnik yang dimainkan di dalam politik lokal di Kota Sorong dalam pemilihan itu, untuk mengguasai sumber daya ekonomi yang banyak di Kota Sorong.

Etnik asli Papua berkolaborasi dengan etnik non Papua dalam merebut kekuasaan di Kota Sorong. Etnik maybrat tidak memilih etnik Moi dikarenakan etnik keduanya mempunyai egoisme kultur dari budaya adat, marga, kampung, dan ingin dominasi etnik satu dengan yang lainnya. Hubungan kedua etnik Papua ini tidak berjalan baik dalam proses pemilihan karena masing-masing saling marginalisasi dengan isu-isu kampaye yang berbauw identitas etnik dan saling menyerang satu dengan yang lainnya. di perluh bantuan kepada etnik non Papua untuk menambah jumlah mayoritas suara pemilih di Kota Sorong, maka etnik non Papua di bernegosiasi dengan perjanjian-perjanjian politik kepada kedua belah pihak maka etnik Maybrat mempunyai perjanjian politik yang di sukai oleh etnik Makassar untuk berkolaborasi dengan etnik Maybrat merebut kekuasaan dalam percaturan politik pemilihan kepala daerah di Kota Sorong. Dalam perjanjian kedua etnik Maybrat menduduki jabatan wakikota dan etnik Makassar menduduki jabatan wakil walikota Sorong. Hubungan yang dibangun oleh etnik Maybrat dengan etnik Makassar sudah jauh hari yang dibangun para elit Maybrat diberikan pendidikan di universitas di Kota Sorong. Dan juga etnik Maybrat sudah menguasai, menjalankan politik identitasnya di Kota Sorong selama 30 tahun lamanya dan juga etnik Maybrat sudah mengguasai jabatan politik dari ketua DPRD kota sorong, banyak anggota dari etnik Maybrat dari berbagai partai politik yang menduduki DPRD kota Sorong, ketua umum dalam berbagaipartai politik, dan proyek-proyek pemerintah di Kota Sorong. Dan etnik Makassar sudah sudah mengguasai perekonomian di kota sorong dari pasar umum, transportasi kendaraan umum, dan sektor perekonomian yang penting di kota sorong, jika ada perjanjian yang politik yang berubah dalam mendukung maka akan berimpas kepada sektor itu juga. Dan juga pembagian Pembagian kekuasan politik yang adil dan dapat dipercaya oleh kedua etnik Maybrat dan etnik Makassar. Etnik Maybrat membuat proses-proses tanah ada etnik Moi di kota sorong, lebih mudah etnik Papau dan etnik non Papua mudah mendapatkan tanah itu karena etnik Maybrat menekan di administrasi dan tidak perduli dengan proses adat mereka. Dari hal-hal ini etnik Papua dan etnik non Papua memberikan dukungan lewat dana maupun basis etnik mereka yang sudah terbanggun seja lama di Kota Sorong. Tujuan kedua etnik Maybrat dengan etnik Makassar berkolaborasi untuk menguasai sumber daya ekonomi ekonomi yang banyak di Kota Sorong. 


\section{DAFTAR PUSTAKA}

Abdillah S.U. (2002). Politik Indentas Etnis, Pengulatan Tanda Tanpa Identitas. Magelang: Penerbit Indonesiatera.

Bucharim, S.A. (2014). Kebangkitan Etnis Menuju Politik Identitas. Jakarta: Yayasan Pustaka Obor Indonesia anggota IKAPI DKI.

Bungin, B. (2001). Metodologi Penelitian Sosial: Format-format Kuantitatif dan Kualitatif. Surabaya: Airlangga University Press.

(2005). Metodologi Penelitian Sosial Kualitatif. Surabaya: Airlangga University Press.

Giddens, A. (2009). Problem Utama Dalam Teori Sosial, menyangkut dengan Aksi,. Struktur, dan Kontradiksi Dalam Analisis Sosial atau dalam judul Asli yang di undu;. Action, Structure, and Contracdition In Social Analysis. Jakarta: Penerbit Pustaka. Pelajar.

Karomani, (2009). Ulama, Jawara, Dan Umaro: Studi Tentang Elite Lokal Di Banten. Sosiohumaniora, Vol. 11 (2): 168-182.

Kubangun I.I. (2014). “Kontestasi Primordialisme dalam Positioning pada Struktur Birokrasi Pemerintahan Kabupaten Manokwari”. Tesis. Yogyakarta: Universitas Gadjah Mada.
Liliweri, A. (2005). Prasangka \& Konflik, Komunikasi Lintas Budaya Masyarakat Multikultur. Yogyakarta: Lkis.

(2009). Prasangka dan Konflik Komunikasi, Lintas Budaya, Masyarakat dan Multikultur. Yogyakarta: Lkis.

Nasir, M. (1988). Metode Penelitian. Jakarta: Ghalia Indonesia.

Nawawi, H.H. (2001). Metodologi Penelitian. Yogyakarta: Bidang Sosial, University Press. , (1991). Metodologi Penelitian Bidang Sosial. Yogyakarta: University Press.

Pandji, S. (2010). Disintegrasi, Pemerintahan Lokal Dan Dana Perimbangan Pusat Dan Daerah. Sosiohumaniora, Vol. 12 (1): 12 - 24.

Salim, A. (2006). Teori dan Paradigma Penelitian Sosial. Yogyakarta: PT. Tiara Wacana.

Singarimbun, M. dan Effendi, S. (1995). Metode Penelitian Survei. Jakarta: LP3ES.

Subianto, Benny. (2009). Ethnic Politics and the Rise of the Dayak Bureaucrats in local Election" dalam Deepening Democracy in Indonesia? Direct Elections for Local Leaders (Pilkada). Maribeth Erb dan Priyambudi Sulistiyanto, Pasir Panjang, Singapura: ISEAS. 